\title{
Genetic variability of Brazilian phytoplasma and spiroplasma isolated from maize plants
}

\author{
Eliane Aparecida Gomes ${ }^{(1)}$, Sílvia Neto Jardim(1), Claudia Teixeira Guimarães ${ }^{(1)}$, \\ Isabel Regina Prazeres de Souza ${ }^{(1)}$ and Elizabeth de Oliveira ${ }^{(1)}$
}

\begin{abstract}
(1)Embrapa Milho e Sorgo, Caixa Postal 151, CEP 35701-970 Sete Lagoas, MG. E-mail: eliane@cnpms.embrapa.br, silvia@icb.ufmg.br, claudia@cnpms.embrapa.br, isabel@cnpms.embrapa.br, beth@cnpms.embrapa.br
\end{abstract}

\begin{abstract}
The objective of this work was to characterize the genetic variability of phytoplasma and Spiroplasma kunkelii isolated from maize plants showing symptoms of stunt collected from different Brazilian geographic regions. A DNA fragment of 500 base pairs (bp) was amplified from the spiralin gene in S. kunkelii and one fragment of 1,200 bp was generated from 16S rDNA gene in phytoplasma. The partial sequences of the spiralin gene showed similarity of $98 \%$ among the isolates of S. kunkelii analyzed. These sequences were compared with the sequence of the spiralin gene from other Spiroplasma species deposited in the GenBank, resulting in a similarity varying from $76.9 \%$ to $88.1 \%$. The $16 \mathrm{~S}$ rDNA sequence from the phytoplasma were completely similar within the Brazilian isolates and showed up to $98 \%$ of the similarity with sequences already found from other phytoplasmas. A very narrow genetic variability was detected by these gene fragments within phytoplasma and Spiroplasma analyzed. However, other genomic regions with higher polymorphic levels shall be identified in order to better evaluate the genetic diversity within these microorganisms population.
\end{abstract}

Index terms: Zea mays, microorganisms, spiralin, mollicutes, genetic polymorphism, gene sequence.

\section{Variabilidade genética de fitoplasma e espiroplasma isolados de plantas de milho no Brasil}

\begin{abstract}
Resumo - O objetivo deste trabalho foi caracterizar a variabilidade genética de isolados de fitoplasma e de Spiroplasma kunkelii obtidos de plantas de milho, apresentando sintomas de enfezamento, coletados em diferentes regiões do Brasil. Um fragmento de 500 pares de bases (pb) do gene que codifica a espiralina de S. kunkelii foi amplificado e um produto de amplificação de 1.200 pb foi gerado a partir do gene 16S rDNA de fitoplasma. As seqüências parciais do gene da espiralina mostraram similaridade de $98 \%$ entre os isolados de S. kunkelii analisados. Essas seqüências foram comparadas com a seqüência do gene da espiralina de outras espécies de Spiroplasma depositadas no GenBank, resultando em similaridade variável entre 76,9\% e 88,1\%. As seqüências do gene 16S rDNA dos isolados de fitoplasma foram completamente similares entre todos os isolados brasileiros e apresentaram até $98 \%$ de similaridade com sequiências do mesmo gene de outros fitoplasmas já publicadas. Uma variabilidade genética muito estreita foi detectada para esses genes entre os isolados de fitoplasma e Spiroplasma analisados. No entanto, outras regiões genômicas, que apresentem um maior polimorfismo precisam ser identificadas para melhor avaliar a diversidade genética dentro da população desses microrganismos.
\end{abstract}

Termos para indexação:Zea mays, microrganismo, espiralina, molicute, polimorfismo genético, sequiência genética.

\section{Introduction}

Maize bushy stunt (MBS) and corn stunt (CS) are two economically important maize (Zea mays L.) diseases, whose incidence has increased recently in Central and Southern America countries, including Brazil (Oliveira et al., 1998; Bedendo et al., 2000).

Two different microorganisms of the Mollicutes class are associated with these diseases. The phytoplasma is believed to be the causal agent of MBS (red stunt) whereas the cause of CS (pale stunt) is Spiroplasma kunkelii, a motile microorganism with helical morphology. Phytoplasmas and spiroplasmas are wallless microorganisms, carrying small genomes with low guanine cytosine (GC) content, whose location are restricted to the phloem tissue of the host plants. These microorganisms are transmitted from plant to plant by phloem-feeding leafhoppers in a persistent propagative manner (Kuske \& Kirkpatrick, 1992). 
Traditionally, phytopathogenic mollicutes were characterized by biological properties, such as symptomatology, range of plant hosts infected and specificity of transmission by vector insects (Liefting et al., 1996). The introduction of immunological methods using polyclonal or monoclonal antibodies have facilitated the studies on mollicutes diseases and improved the ability to detect several phytopathogenic mollicutes including S. kunkelli and the MBS phytoplasma (Chen \& Jiang, 1988; Hsu et al., 1990). Sensitive and specific detection of mollicutes in their host plant was also achieved by DNA hybridization utilizing cloned random fragments of phytoplasma DNA as probes (Kison et al., 1994) and amplification of 16S rDNA genes (Gundersen et al., 1996). Deng \& Hiruki (1991) used primers for selective amplification of the 16S rDNA subunit from phytoplasma, which have been considered one of the best methods to detect diseases related to phytoplasmas (Gundersen et al., 1996; Marcone et al., 1997). Primers amplifying a specific region of the spiralin gene, the main membrane protein in spiroplasmas, were described by Barros et al. (2001) and have been used to identify $S$. kunkelii isolates. The spiralin gene encompasses variable and conserved regions that enabled the design of specific primers to detect and identify other species of Spiroplasma from group I. These primers amplify DNA of S. kunkelii, generating a fragment of approximately $500 \mathrm{bp}$, without amplifying DNA of phytoplasma or other Spiroplasma species tested. The availability of specific and accurate techniques for detection of the corn stunt causal agent can facilitate the study of the ecology of the pathogen, as well as its influence in the incidence and transmission of this disease in maize and other cultivated species (Barros et al., 2001).

The objective of this work was to characterize the genetic variability of phytoplasma and Spiroplasma kunkelii isolated from maize plants showing symptoms of stunt and collected from different Brazilian geographic regions.

\section{Material and Methods}

\section{Plant material and DNA extraction}

Maize leaves with stunt symptoms (pale and red stunt) were collected from different corn production regions in Brazil (Table 1), frozen in liquid nitrogen and immediately stored at $-80^{\circ} \mathrm{C}$ upon arriving in the laboratory. Total DNA of symptomatic plants was extracted from the midribs of the leaves according to Saghai-Maroof et al. (1984).

\section{PCR amplification and DNA sequencing}

The primer pairs CSSF2 and CSSR6 (Barros et al., 2001), R16R2 and R16F2 (Lee et al., 1993) were used in the amplification of $S$. kunkelii spiralin gene fragment and the phytoplasma 16S rDNA gene, respectively. Amplification reactions were performed by PCR multiplex, with both primers pairs (CSSF2-CSSR6 and R16R2-R16F2) $10 \mu \mathrm{M}$ each; $20 \mathrm{mM}$ Tris-HCl; $50 \mathrm{mM}$ $\mathrm{KCl} ; 2 \mathrm{mM} \mathrm{MgCl} 2 ; 0.1 \mathrm{mM}$ of each dNTP; $1 \mathrm{U}$ of Taq DNA polymerase and $50 \mathrm{ng}$ DNA in a final volume of $25 \mu \mathrm{L}$. The DNA samples were amplified in a 9,600 model thermocycler (Applied Biosystems, Foster City, CA, USA), programmed for $94^{\circ} \mathrm{C}$ for $30 \mathrm{sec}$, followed by 35 cycles $\left(94^{\circ} \mathrm{C}, 15 \mathrm{sec} ; 50^{\circ} \mathrm{C}, 15 \mathrm{sec} ; 72^{\circ} \mathrm{C}\right.$, $15 \mathrm{sec}$ ) and one extension step of $5 \mathrm{~min}$ at $72^{\circ} \mathrm{C}$. Negative controls with no DNA template were included in each experiment. Positive controls for phytoplasma and spiroplasma were also used.

Amplification products were analyzed in a $0.8 \%$ agarose gel immersed in TAE buffer $(40 \mathrm{mM}$ Trisacetate; $1 \mathrm{mM}$ EDTA, pH 8.0) by electrophoresis for 3-4 hours at $100 \mathrm{~V}$. The gels were stained with ethidium bromide $\left(0.5 \mu \mathrm{g} \mathrm{mL}^{-1}\right)$, the images captured under UV light and stored using the Eagle Eye II photodocumentation system. The PCR fragments used for sequencing (Figure 1) were purified with the QIAquick Gel Extraction kit according to the manufacturer's instructions. The purified fragments were sequenced using the Big Dye Terminator v. 2.0 in an ABI Prism 377 sequencer.

\section{Sequence analysis}

Each isolate was sequenced at least in three replicates and a final edited sequence was obtained using the module Seqman of DNAStar until no doubt related to the base quality has been reached. The edited sequences

Table 1. Collection of spiroplasma and phytoplasma isolated from maize fields.

\begin{tabular}{lcllc}
\hline \multicolumn{2}{c}{ Spiroplasma } & & \multicolumn{2}{c}{ Phytoplasma } \\
\cline { 1 - 2 } \cline { 5 - 5 } \multicolumn{1}{c}{ Local } & Isolate & & Local & Isolate \\
\hline Assis, SP & $102,166,173$ & & Assis, SP & $18,22,91,99$ \\
Santa Helena, GO & $65,67,198$ & & Capão Bonito, SP & $78,82,153,157$ \\
Sete Lagoas, MG & $24 \mathrm{~B}$ & & Sete Lagoas, MG & $24,5 \mathrm{~B}, 8 \mathrm{~B}, 10 \mathrm{~B}$ \\
Dourados, MS & $4,6,9,18$ & & Dourados, MS & 2 \\
& & & Jardinópolis, SP & 235 \\
\hline
\end{tabular}


were compared with each other using the CLUSTAL W 1.8 software (Thompson et al., 1994), and the comparisons with the GenBank Nucleotide Database (http://www.ncbi.nlm.nih.gov) were performed by the algorithm BLAST (Altschul et al., 1997). Aligned sequences from the isolates and GenBank were grouped in a consensus tree by the module MegAlign of DNAStar.

\section{Results and Discussion}

The multiplex PCR using DNA from infected plant amplified a fragment of $500 \mathrm{bp}$, corresponding to Spiroplasma kunkelii spiralin gene and another fragment of 1,200 bp, related to the $16 \mathrm{~S}$ rDNA gene from phytoplasma (Figure 2). Both phytopathogens were detected in plants collected in Assis, SP, Sete Lagoas, MG and Dourados, MS, while plants from Santa Helena, GO, showed only spiroplasma fragments, and samples from Capão Bonito, SP and Jardinópolis, SP, were infected only by phytoplasma (Table 1). The multiplex PCR test is an important tool to identify precisely the causal agent of corn stunt affecting maize fields. Additionally, it has been used to evaluate the levels and sources of resistance to corn stunt, aiming to assist the selection of plant breeding programs (Silva et al., 2002).

Nucleotide sequences obtained from the spiralin gene of eleven S. kunkelii isolates were compared to each other showing a similarity of $98 \%$. The S. kunkelii spiralin gene (accession number U57659), which have 240 amino acids (Foissac et al., 1997), was the closest sequence deposited in the GenBank, presenting also 98\% of similarity. The comparison with the nucleotide sequence of spiralin gene from other Spiroplasma species, belonging to group I, resulted in $76.9 \%$ to $88.1 \%$
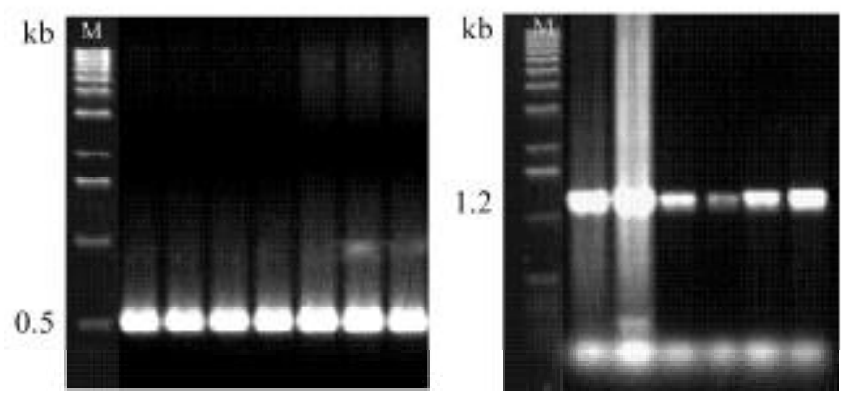

Figure 1. Gel electrophoresis of polymerase chain reaction (PCR) fragments of the spiralin gene of Spiroplasma (left) and $16 \mathrm{~S}$ rDNA region of phytoplasma isolates (right). (M) 1 kb DNA Ladder. of similarity. According to the phylogenetic tree based on the sequence similarity data obtained from comparison between S. kunkelii, S. citri (U13998), S. melliferum (M59366) and S. phoeniceum (U57658), the S. kunkelii isolates constitute a separated group from the others (Figure 3).

These results are in agreement with Foissac et al. (1997), who found $78 \%$ of similarity when comparing a $1,021 \mathrm{bp}$ sequences of the spiralin gene from $S$. kunkelii and S. citri. Additionally, Barros et al. (2001) compared nucleotide sequence from isolates belonging to four different Spiroplasma group I species and observed a similarity of $73.5 \%, 76.7 \%$ and $88.1 \%$ between S. kunkelii and S. citri, S. melliferum and S. phoeniceum, respectively. As the first work evaluating the genetic diversity within the spiroplasma species based on sequence data, the spiralin gene have shown polymorphisms among the close related species, but this polymorphism may not be enough to distinguish isolates within species. However, using the same sequence fragment, it can be highlighted that the genetic diversity within S. kunkelli isolates infecting maize fields in Brazil is very narrow.

Analysis of 1,200-nucleotide sequence of 16S rDNA did not show any difference among the fourteen phytoplasma isolates from Brazilian maize fields. These sequences showed a $98 \%$ of similarity when compared to the other 16S rDNA sequences from the 16SrI group phytoplasmas (B subgroup) described by Lee et al.

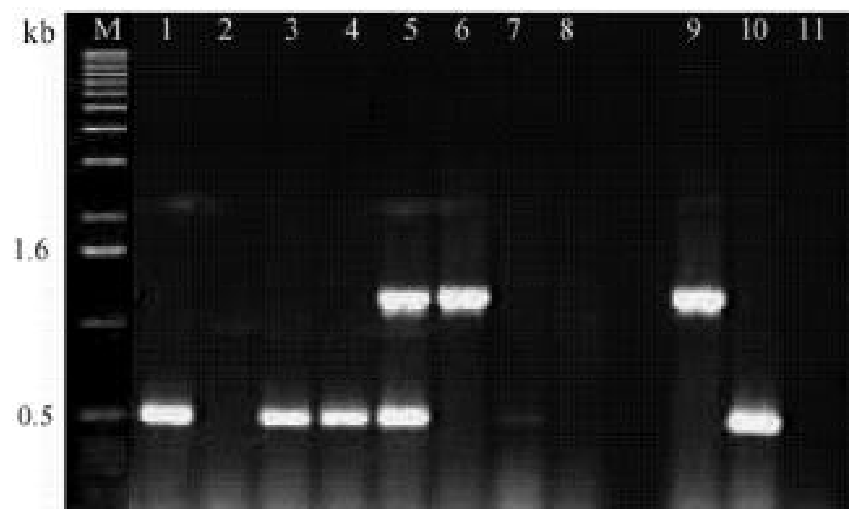

Figure 2. Gel electrophoresis of polymerase chain reaction (PCR) fragments of spiralin gene of Spiroplasma and 16S rDNA gene of phytoplasma isolates: (M) $1 \mathrm{~kb}$ DNA Ladder; samples 1, 3, 4 show the Spiroplasma fragment; sample 6 shows the phytoplasma fragment; sample 5 shows the presence of both microorganisms; samples 2, 7, 8 show negative results for both microorganisms; line 9: phytoplasma positive control; line 10: Spiroplasma positive control and line 11: negative control. 


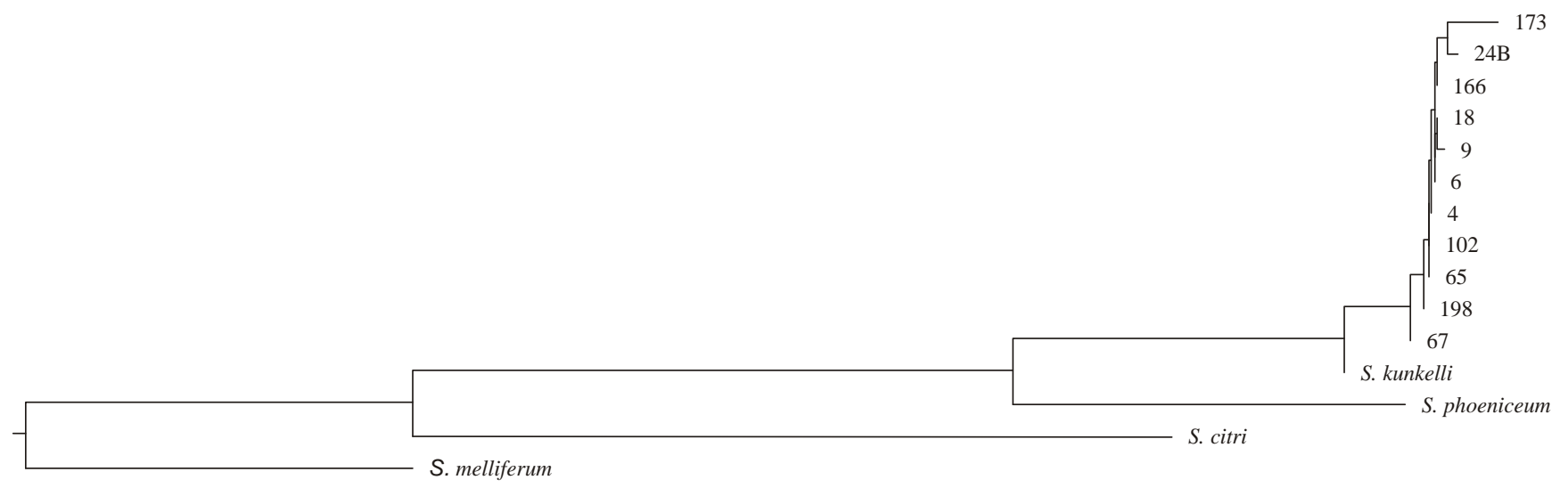

Figure 3. Phylogenetic tree based on similarity data obtained from comparison of spiralin gene fragment sequence among S. kunkelli isolates listed in the Table 1 and other Spiroplasma species sequences deposited in the GenBank: S. kunkelii (U57659), S. citri (U13998), S. melliferum (M59366) and S. phoeniceum (U57658).

(1993). Maize Bushy Stunt Phytoplasma is the only phytoplasma in this subgroup that infects maize. Up to now a small part of the genome-like ribosomal protein genes, rDNA genes (16S and 23S) and spacer region between $16 \mathrm{~S}$ and $23 \mathrm{~S}$ rDNA have been used in phytoplasma genetic variability studies. The RFLP pattern of ribosomal gene of phytoplasma isolates from Brazilian maize plants were analyzed by Bedendo et al. (2000), showing no efficiency to detect genetic differences among them. Guo \& Cheng (2000) used RFLP pattern of 16S, 23S and two ribosomal proteins genes to study Chokecherry phytoplasmas (ChX) without identifying any difference among the isolates. The high degree of conservation within the phytoplasmas subgroups was also revealed by sequence analysis, a more accurate and sensitivity molecular technique.

The sequencing of S. kunkeli spiralin gene fragment and phytoplasma 16S rDNA gene detected a little or none genetic variability among isolates of these organisms collected from different regions of Brazil. Thus, the hypothesis of a narrow genetic variability within spiroplasma and phytoplasma populations can be raised and endorsed by these data, even when the isolates were collected from very different geographic and edaphoclimatic regions.

\section{Conclusions}

1. Based on spiralin gene and $16 \mathrm{~S}$ rDNA, there is a narrow genetic variability within spiroplasma and phytoplasma populations collected from different Brazilian regions.

2. The polymorphism identified among the isolates of phytoplasma and spiroplasma species can be used to monitor the incidence of the corn stunt in the Brazilian regions.

\section{Acknowledgements}

To Prodetab/Embrapa for financial support.

\section{References}

ALTSCHUL, S.F.; MADDEN, T.L.; SCHÄFFER, A.A.; ZHANG, J.; ZHANG, Z.; MILLER, W.; LIPMAN, D.J. Gapped BLAST and PSI-BLAST: a new generation of protein database search programs. Nucleic Acids Research, v.25, p.3389-3402, 1997.

BARROS, T.S.L.; DAVIS, R.E.; RESENDE, R.O.; DALLY, E.L. Design of a polymerase chain reaction for specific detection of corn stunt spiroplasma. Plant Disease, v.85, p.475-480, 2001.

BEDENDO, I.P.; DAVIS, R.E.; DALLY, E.L. Detection and identification of the maize bushy stunt phytoplasma in corn plants in Brazil using PCR and RFLP. International Journal of Pest Management, v.46, p.73-76, 2000.

CHEN, T.A.; JIANG, X.F. Monoclonal antibodies against the maize bushy stunt agent. Canadian Journal of Microbiology, v.34, p.6$11,1988$.

DENG, S.; HIRUKI, C. Amplification of 16S rRNA genes from culturable and non-culturable Mollicutes. Journal of Microbiological Methods, v.14, p.53-61, 1991.

FOISSAC, X.; JOSEPH, M.B.; SAILLARD, C. Sequence analysis of Spiroplasma phoeniceum and Spiroplasma kunkelii spiralin genes 
and comparison with other spiralin genes. Current Microbiology, v.35, p.240-243, 1997.

GUNDERSEN, D.E.; LEE, I.M.; SCHAFF, D.A.; HARRISON, N.A.; CHANG, C.J.; DAVIS, R.E.; KINGSBURY, D.T. Genomic diversity and differentiation among phytoplasma strains in the $16 \mathrm{~S}$ rRNA groups I (aster yellows and related phytoplasmas) and III (X-disease and related phytoplasmas). International Journal of Systematic Bacteriology, v.46, p.64-75, 1996.

GUO, Y.H.; CHENG, Z.M. Characterization of X-disease phytoplasmas in chokecherry from North Dakota by PCR-RFLP and sequence analysis of the rRNA gene region. Plant Disease, v.84, p.1235-1240, 2000.

HSU, H.T.; LEE, I.M.; DAVIS, R.E.; WANG, Y.C. Immunization for generation of hybridoma antibodies specifically reacting with plants infected with a mycoplasmalike organism (MLO) and their use in detection of MLO antigens. Phytopathology, v.80, p.946950, 1990.

KISON, H.; SCHNEIDER, B.; SEEMÜLLER, E. Restriction fragment length polymorphism within the apple proliferation mycoplasmalike organism. Journal of Phytopathology, v.141, p.395401, 1994.

KUSKE, C.R.; KIRKPATRICK, B.C. Phylogenetic relationships between the western aster yellows mycoplasmalike organism and other prokaryotes established by $16 \mathrm{~S}$ rRNA gene sequence. International Journal of Systematic Bacteriology, v.42, p.226233, 1992.

LEE, I.M.; HAMMOND, R.W.; DAVIS, R.E.; GUNDERSEN, D.E. Universal amplification and analysis of pathogen 16S rDNA for classification and identification of mycoplasmalike organisms. Phytopathology, v.83, p.834-842, 1993.

LIEFTING, L.W.; ANDERSEN, M.T.; BEEVER, R.E.; GARDNER, R.C.; FORSTER, R.L.S. Sequence heterogeneity in the two 16S rRNA genes of Phormium yellow leaf phytoplasma. Applied and Environmental Microbiology, v.62, p.3133-3139, 1996.

MARCONE, C.; RAGOZZINO, A.; SEEMÜLLER, E. Detection and identification of phytoplasmas in yellow-diseased weeds in Italy. Plant Pathology, v.46, p.530-537, 1997.

OLIVEIRA, E.; WAQUIL, J.M.; FERNANDES, F.T.; PAIVA, E.; RESENDE, R.O.; KITAJIMA, E.W. "Enfezamento pálido" e "enfezamento vermelho" na cultura do milho no Brasil Central. Fitopatologia Brasileira, v.23, p.45-47, 1998.

SAGHAI-MAROOF, M.A.; SOLIMAN, K.M.; JORGENSEN, M.A.; ALLARD, R.W. Ribosomal DNA spacer-length polymorphisms in barley: Mendelian inheritance, chromosomal location, and population dynamics. Proceedings of the National Academy of Sciences of the United States of America, v.81, p.8014-8018, 1984.

SILVA, R.G.; GALVÃO, J.C.C.; MIRANDA, G.V.; OLIVEIRA, E. Identificação dos níveis e fontes de resistência aos enfezamentos do milho. Revista Brasileira de Milho e Sorgo, v.1, p.18-29, 2002.

THOMPSON, J.D.; DIGGINS, D.G.; GIBSON, T.J. CLUSTAL $\mathrm{W}$ : improving the sensitivity of progressive multiple sequence alignment through sequence weighting, position-specific gap penalties and weight matrix choice. Nucleic Acids Research, v.22, p.4673-4680, 1994.

Received on July 3, 2003 and accepted on November 19, 2003 